Special Issue of the 7th International Advances in Applied Physics and Materials Science (APMAS 2017)

\title{
Synthesis of $\mathrm{B}_{4} \mathrm{C}-\mathrm{SiC}$ in-Situ Composite Powders through Carbothermic Reactions
}

\author{
F. ÇALIŞKAN ${ }^{a, *}$, E. KOCAMAN ${ }^{b}$ AND T. TEHÇI $^{c}$ \\ ${ }^{a}$ Sakarya University, Department of Metallurgy and Material Engineering, 54100 Sakarya, Turkey \\ ${ }^{b}$ Bulent Ecevit University, Department of Metallurgy and Materials Engineering, 67000 Zonguldak, Turkey \\ ${ }^{c}$ Sakarya University, Vocational School of Karasu, 54500 Sakarya, Turkey
}

\begin{abstract}
In recent years silicon carbide $(\mathrm{SiC})$ has drawn attention due to its outstanding useful physical and chemical properties such as high hardness, low density, superior chemical inertness etc. Thus, SiC is a strong candidate for several high-tech applications. Numerous attempts have been made to improve its performance. Hard ceramic particles $\left(\mathrm{TiB}_{2}, \mathrm{~B}_{4} \mathrm{C}, \mathrm{TiC}\right.$, and $\mathrm{Al}_{2} \mathrm{O}_{3}$ etc.) were added to $\mathrm{SiC}$ matrix to improve its mechanical properties. In the current study, $\mathrm{B}_{4} \mathrm{C}-\mathrm{SiC}$ in-situ composite powders were synthesized successfully via mechanochemical processing by using a powder mixture of $\mathrm{B}_{4} \mathrm{C}, \mathrm{SiO}_{2}$ and black carbon. After mechanical preparation, the powder mixtures have reacted at $1400-1600{ }^{\circ} \mathrm{C}$ for various time intervals under $\mathrm{Ar}$ atmosphere. The resulting powders were characterized by XRD. Microstructure investigations were carried out to determine the distribution and morphology of $\mathrm{SiC}$ and $\mathrm{B}_{4} \mathrm{C}$ grains. The XRD pattern of the yield powder reveals $\mathrm{B}_{4} \mathrm{C}-\mathrm{SiC}$ biphase composite powder. SEM images show net-shaped fibrous $\mathrm{SiC}$ structures and ultra-fine nanofibrous particles of 50-100 nm in diameter.
\end{abstract}

DOI: 10.12693/APhysPolA.134.113

PACS/topics: carbothermic reduction, carburization, silicon carbide, boron carbide

\section{Introduction}

Development of $\mathrm{SiC}$ ceramics for aerospace and $\mathrm{nu}-$ clear industries, for bearings, mechanical seals, nozzles, turbine parts, heat exchangers, cylinder liners, and for cutting tools have recently been in the focus of research, because of their superior properties, such as low density, high strength and toughness, high melting points, good oxidation and thermal shock resistance [1-8]. For this reason $\mathrm{SiC}$ can be chosen as a better candidate material by a number of researchers $[9,10]$.

$\mathrm{SiC}-\mathrm{B}_{4} \mathrm{C}$ composite materials have been shown to have a combination of desirable mechanical and thermal properties in recent investigations [11]. $\quad \mathrm{SiC}_{-} \mathrm{B}_{4} \mathrm{C}$ composite ceramics can offer a combination of high hardness and fracture toughness with a light weight. This type of hybrid ceramics can be produced by several methods, such as carbothermal reduction and carburization (CRC), mechanical alloying, spark plasma sintering and hot pressing [12].

Carbothermal reduction method can be classified as an easier and cheaper method [13-15]. Corresponding reactions are shown in Eqs. (1) and (2). With a similar method $\mathrm{SiC}$ can be synthesized from $\mathrm{SiO}_{2}$ starting material by using carbon reducing agent though Eq. (3).

$$
\begin{aligned}
& \mathrm{B}_{2} \mathrm{O}_{3}+7 \mathrm{C}=\mathrm{B}_{4} \mathrm{C}+6 \mathrm{CO}, \\
& 4 \mathrm{H}_{3} \mathrm{BO}_{3}+7 \mathrm{C}=\mathrm{B}_{4} \mathrm{C}+6 \mathrm{CO}+6 \mathrm{H}_{2} \mathrm{O}, \\
& \mathrm{SiO}_{2}+3 \mathrm{C}=\mathrm{SiC}+2 \mathrm{CO} .
\end{aligned}
$$

\footnotetext{
*corresponding author; e-mail: fcaliskan@sakarya.edu.tr
}

The addition of some seeding additives $\left(\mathrm{B}_{4} \mathrm{C}\right.$ or $\left.\mathrm{SiC}\right)$ to the carbothermal reduction and carburization (CRC) can change transformation kinetics of reaction due to nucleation effect. The reaction (1) consist of two main reactions, given by Eqs. (5) and (6). The first one is the reaction of $\mathrm{SiO}_{2}$ with $\mathrm{B}_{4} \mathrm{C}$ to form $\mathrm{SiC}, \mathrm{B}_{2} \mathrm{O}_{3}$, and C. The second is the reaction of intermediate products with $\mathrm{C}$, such that all $\mathrm{C}$ in solid state oxides to $\mathrm{CO}$ above $1558^{\circ} \mathrm{C}$ [8].

$$
\begin{aligned}
& \mathrm{B}_{4} \mathrm{C}+\mathrm{SiO}_{2}+3 \mathrm{C}=\mathrm{B}_{4} \mathrm{C}+\mathrm{SiC}+2 \mathrm{CO} \\
& 5 / 2 \mathrm{~B}_{4} \mathrm{C}+3 \mathrm{SiO}_{2}=3 \mathrm{SiC}+2 \mathrm{~B}_{2} \mathrm{O}_{3}+5 / 2 \mathrm{C} \\
& \mathrm{B}_{4} \mathrm{C}+\mathrm{SiO}+2 \mathrm{~B}_{2} \mathrm{O}_{3}+7 \mathrm{C}=2 \mathrm{~B}_{4} \mathrm{C}+\mathrm{SiO}+6 \mathrm{CO} .
\end{aligned}
$$

In the present study, the carbothermic method has been used to synthesize silicon carbide powder from high purity silica and carbon black raw materials. In addition, effects of the $\mathrm{B}_{4} \mathrm{C}$ and $\mathrm{SiC}$ nucleants on this reaction were investigated in detail.

\section{Experimental}

The purpose of the present study was to synthesize $\mathrm{SiC} / \mathrm{B}_{4} \mathrm{C}$ composite powders by using silica and carbon starting materials and the $\mathrm{CRC}$ method. The nucleation effect of $\mathrm{B}_{4} \mathrm{C}$ and $\mathrm{SiC}$ on synthesis of $\mathrm{SiC}$ by carbothermal reactions was investigated by changing the stoichiometric ratios, and the amount and the type of seeding additive. The compositions of the samples used in the experimental procedure are shown in Table I.

$\mathrm{SiO}_{2}$ used in this study was obtained from Ege Kimya Company, Turkey. Carbon black (Vulcan XC 72), which was used as the reducing agent, was received from Cabot. It had purity of $99.7 \%$ and the specific surface area of $110 \mathrm{~m}^{2} \mathrm{~g}^{-1}$. Second phase component, the boron carbide, having the mean particle size of $10 \mu \mathrm{m}$ was received from Alfa Aesar. SiC powders were used as the nucleant material. 
Compositions used in experiments (wt.\%). TABLE I

\begin{tabular}{c|c|c|c|c}
\hline \hline Exp. No. & $\mathrm{SiO}_{2}$ & $\mathrm{C}$ & $\mathrm{B}_{4} \mathrm{C}$ & $\mathrm{SiC}$ \\
\hline 1 & 1.25 & 3.75 & - & - \\
2 & 1.25 & 3.75 & - & - \\
3 & 1.00 & 4.00 & - & 1.00 \\
4 & 1.19 & 3.57 & 0.25 & - \\
5 & 1.13 & 3.58 & 0.50 & - \\
6 & 1.07 & 3.19 & 0.75 & - \\
7 & 1.13 & 3.38 & 0.25 & 0.25 \\
8 & 1.07 & 3.19 & 0.50 & 0.25 \\
9 & 1.00 & 3.00 & 0.75 & 0.25 \\
10 & 1.00 & 3.00 & 0.50 & 0.50 \\
11 & 1.00 & 3.00 & 1.00 & -
\end{tabular}

Silica was mixed with carbon black just above the stoichiometric ratio according to reaction (3). $\mathrm{B}_{4} \mathrm{C}$ or $\mathrm{SiC}$ was added at different ratios according to Table I. Each powder mix (except exp. 1) was milled for about $24 \mathrm{~h}$ in a polyethylene bottle with a zirconia ball.

The CRC reactions were carried out using a tube furnace (Protherm PTF Series) under Ar (99.999 purity, Linde Group, Turkey) at $1400-1600^{\circ} \mathrm{C}$ for $4 \mathrm{~h}$. After the reaction, the product was heated in an ashing furnace to burn out the residual carbon in air at $900^{\circ} \mathrm{C}$ for $2 \mathrm{~h}$.

Powder morphology was revealed using scanning electron microscopy (SEM) and energy dispersive spectrometry (EDS) was used to determine the elemental composition. The yield powders were analyzed using an X-ray diffractometer (Rigaku D/MAZ/2200/PC, Japan) with $\mathrm{Cu} \mathrm{K} \mathrm{K}_{\alpha}$ radiation source $(\lambda=1.540454 \AA$ to identify the synthesized phases.

\section{Results and discussion}

Diffraction pattern in Fig. 1 belongs to the produced powders with various compositions. The results show that $\beta$ - $\mathrm{SiC}, \mathrm{SiO}_{2}, \mathrm{~B}_{4} \mathrm{C}$ and amorphous phases were formed at various rates. The conversion from $\mathrm{SiO}_{2}$ to $\mathrm{SiC}$ was achieved above $1500^{\circ} \mathrm{C}$ with $\mathrm{B}_{4} \mathrm{C}$ mostly staying stable.

Sample in Fig. 1a gave better results than samples in Fig. $1 \mathrm{~b}$ and c. Minor amount of silica remained as an unreacted reactant. All samples contain amorphous phase with amount decreasing from Fig. 1c to Fig. 1a. There was obviously an increase in the amount of $\mathrm{B}_{4} \mathrm{C}$ resulting in the increase in the amount of non-crystalline phases. The dominant phase for all compositions was $\mathrm{SiC}$, having peaks with strong intensity. In this case $\mathrm{SiC}$ can be accepted as the matrix phase in the synthesized composite powder as was initially assumed. These results explain that the in-situ $\mathrm{SiC}_{-} \mathrm{B}_{4} \mathrm{C}$ composites can be successfully synthesized with composition number 4 .

SEM micrograph and elemental analysis of the $\mathrm{SiC}$ powders synthesized after $\mathrm{CRC}$ at $1450{ }^{\circ} \mathrm{C}$ for $4 \mathrm{~h}$ from the sample with 20 wt.\% of $\mathrm{SiC}$ nucleant is given in Fig. 2.

Previous works have shown that synthesis temperatures under $1500^{\circ} \mathrm{C}$ were not adequate for the conversion

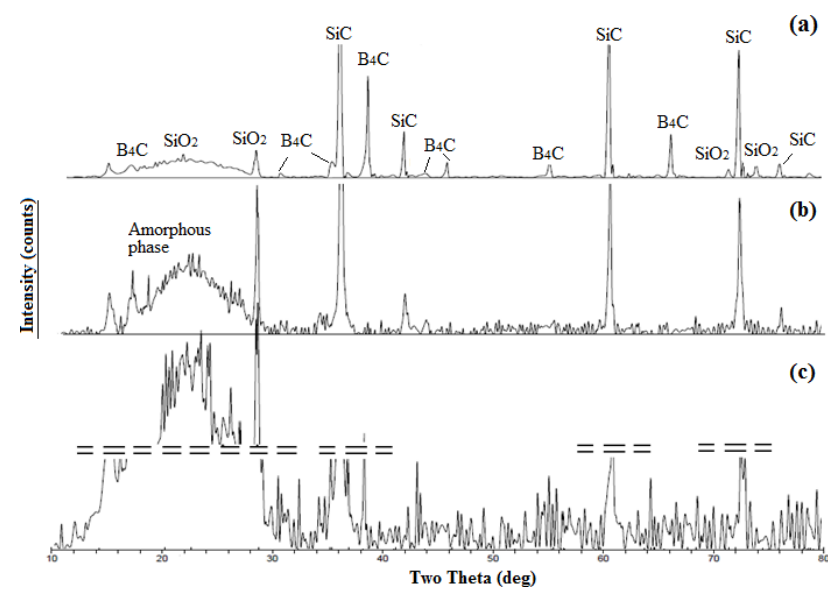

Fig. 1. X-ray diffraction patterns after synthesis of sample 4 (a), sample 7 (b) and sample 11 (c).

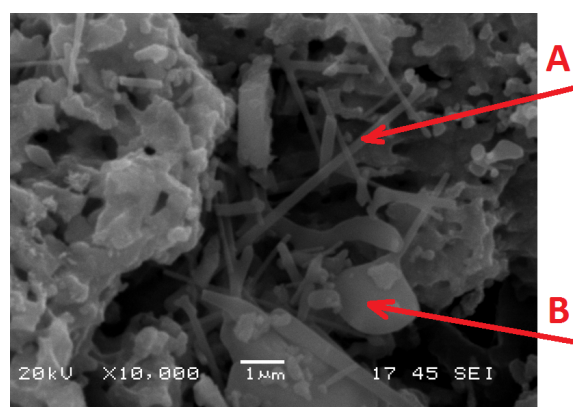

Fig. 2. SiC particles after CRC at $1450{ }^{\circ} \mathrm{C}$ for $4 \mathrm{~h}$, synthesized from the sample with 20 wt.\% of SiC nucleant.

of $\mathrm{SiO}_{2}$ to $\mathrm{SiC}$. SiC fibrous grains (A point in Table II) can be obviously seen in Fig. 2. In addition, unconverted $\mathrm{SiO}_{2}$ particles (B point in Table III) can be also present. $\mathrm{SiC}$, added to the starting powders, acted as seedingagent and supported the $\mathrm{SiC}$ formation mechanism and the conversion.

EDS analysis of A point in Fig. 2.

TABLE II

\begin{tabular}{c|c|c|c|c}
\hline \hline Elem. & Line & $\begin{array}{c}\text { Intensity } \\
{[\text { counts/s] }}\end{array}$ & $\begin{array}{c}\text { Error, } \\
2 \text {-sig. }\end{array}$ & $\begin{array}{c}\text { Concentration } \\
{[w t . \%]}\end{array}$ \\
\hline $\mathrm{C}$ & $\mathrm{Ka}$ & 112 & 6.692 & 45.107 \\
$\mathrm{O}$ & $\mathrm{Ka}$ & 4.75 & 1.378 & 8.160 \\
$\mathrm{Si}$ & $\mathrm{Ka}$ & 564 & 15.021 & 46.733
\end{tabular}

As is shown in Fig. 3, the SEM micrograph consists of fibrous particles of 50-100 $\mathrm{nm}$ in diameter. Very net shaped super nano-rods can easily be seen in Fig. 3. The SEM micrograph of Fig. 3 shows ultra-high aspect ratio of the particles. It is apparent that in Fig. 3 the $\mathrm{SiC}$ super nanorods are generally straight and have a preferential axis orientation and in addition interact with each other. Y.H. Gao et al. [16] and F. Çalıskan et al. [17] revealed that the axis of orientation of the $\mathrm{SiC}$ is constant along the length of the nanorod. 
EDS analysis of B point in Fig. 2.

TABLE III

\begin{tabular}{c|c|c|c|c}
\hline \hline Elem. & Line & $\begin{array}{c}\text { Intensity } \\
{[\text { counts/s] }}\end{array}$ & $\begin{array}{c}\text { Error, } \\
\text { 2-sig. }\end{array}$ & $\begin{array}{c}\text { Concentration } \\
{[\text { wt.\%] }}\end{array}$ \\
\hline $\mathrm{C}$ & $\mathrm{Ka}$ & 0.00 & 0.000 & 0.000 \\
$\mathrm{O}$ & $\mathrm{Ka}$ & 76.85 & 5.544 & 47.702 \\
$\mathrm{Si}$ & $\mathrm{Ka}$ & 43.91 & 3.093 & 13.791
\end{tabular}

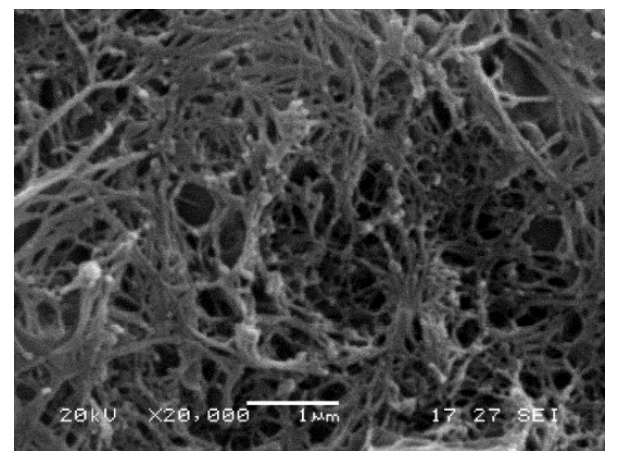

Fig. 3. $\mathrm{SiC}$ particles after $\mathrm{CRC}$ at $1550^{\circ} \mathrm{C}$ for $4 \mathrm{~h}$, synthesized from the sample added with 5 wt. $\%$ of $\mathrm{SiC}$ and 5 wt. $\%$ of $\mathrm{B}_{4} \mathrm{C}$ nucleants.

During the in-situ synthesis of the $\mathrm{SiC}_{-} \mathrm{B}_{4} \mathrm{C}$ composites, after heating the powder mixture with the stoichiometric ratio to the reaction of components, the glassy phase was observed, shown in Fig. 4. It is clear that the $\mathrm{SiC}$ particles were covered by boron oxide glass. This can be due to reaction from Eq. (5), because $\mathrm{B}_{4} \mathrm{C}$ can react with $\mathrm{SiO}_{2}$ and can form $\mathrm{B}_{2} \mathrm{O}_{3}$ plus carbon and $\mathrm{SiC}$. Authors think that while this mechanism supports $\mathrm{SiC}$ formation, the decomposition of $\mathrm{B}_{4} \mathrm{C}$ to $\mathrm{B}_{2} \mathrm{O}_{3}$ increases with the increase of $\mathrm{B}_{4} \mathrm{C}$. EDS analysis in Fig. $4 \mathrm{~b}$ shows that $\mathrm{B}$ and $\mathrm{O}$ elements were detected together instead of $\mathrm{B}$ and $\mathrm{C}$. This observation supports $\mathrm{B}_{4} \mathrm{C}$ decomposition mechanism and formation of the glassy phase.
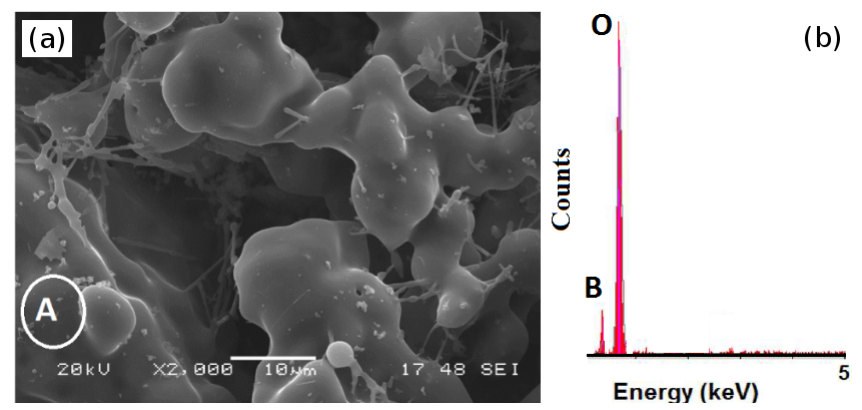

Fig. 4. (a) SEM image of sample with composition $\mathrm{nr} 7$ after CRC conversion at $1550^{\circ} \mathrm{C}$ (a), EDS analysis of region $\mathrm{A}(\mathrm{b})$.

As seen in Fig. 2, the XRD results are in accordance with SEM and EDS analyses. Authors think that such process can result in perfectly bonded fiber-matrix interface after sintering, as can be seen in Fig. 4a.

\section{Conclusions}

Present paper is focused on the synthesis of $\mathrm{SiC}-\mathrm{B}_{4} \mathrm{C}$ composite powder by CRC method. In this study the targeted objectives were achieved by processing the samples at $1550{ }^{\circ} \mathrm{C}$ for $4 \mathrm{~h}$. Ultra-fine $\mathrm{SiC}$ nanorods with a diameter of 50-100 nm and net shaped very fine fibrous particles have been synthesized by $\mathrm{CRC}$ reaction. While $\mathrm{SiC}$ was the constantly dominant phase, $\mathrm{B}_{4} \mathrm{C}$ has been the reinforcing phase. $\mathrm{B}_{2} \mathrm{O}_{3}$ glassy phase formation owing to the reaction between $\mathrm{SiO}_{2}$ and $\mathrm{B}_{4} \mathrm{C}$ was observed at high $\mathrm{B}_{4} \mathrm{C} / \mathrm{SiO}_{2}$ ratios. Authors think that after sintering the synthesized $\mathrm{SiC}_{-} \mathrm{B}_{4} \mathrm{C}$ composite powder will exhibit superior hardness, higher fracture toughness, higher compressive strength etc. than those of $\mathrm{SiC}-\mathrm{B}_{4} \mathrm{C}$ powder mixture, prepared by conventional mixing methods. In conclusion, ultrafine $\mathrm{SiC}_{-} \mathrm{B}_{4} \mathrm{C}$ composite ceramic powder could be synthesized by an inexpensive CRC process. In addition, SiC- $\mathrm{B}_{4} \mathrm{C}$ particles were significantly homogeneously distributed via the $\mathrm{CRC}$ method and the mismatch between the matrix and the reinforcement was minimized.

\section{References}

[1] M. Singh, Scripta Mater. 34, 923 (1996).

[2] Z. Zhang, X. Du, W. Wang, Z. Fu, H. Wang, Int. J. Refract. Met. Hard Mater. 41, 270 (2013).

[3] N.P. Padture, J. Am. Ceram. Soc. 77, 519 (1994).

[4] X.L. Shi, F.M. Xu, Y. Tan, L. Wang, Processing and properties of advanced ceramics and composites II 265, 189 (2012).

[5] A. Sanders, I. Tibbitts, D. Kakarla, S. Siskey, J. Ochoa, K. Ong, R. Brannon, Dynamic Behavior of Materials 1, 229 (2011).

[6] S. Gupta, S.K. Sharma, B. Venteka, M. Kumar, Y.W. Kim, Ceram. Intern. 41, 14780 (2015).

[7] S. Lafon-Placette, K. Delbe, J. Denape, M. Ferrato, J. Eur. Ceram. Soc. 35, 1147 (2015).

[8] K.J. Kim, J.H. Eom, Y.W. Kim, W.S. Seo, Ceram. Intern. 43, 5343 (2017).

[9] Z. Zhang, X. Du, Z. Li, W. Wang, J. Zhang, Z. Fu, J. Eur. Ceram. Soc. 34, 2153 (2014).

[10] Z. Zhang, X. Du, J. Wang, W. Wang, Y. Wang, Z. Fu, Powder Technol. 254, 131 (2014).

[11] P. Sahani, S.K. Karak, B. Mishra, D. Chakravarty, D. Chaira, Int. J. Refract. Met. Hard Mater. 57, 31 (2016).

[12] X. Zhang, Z. Zhang, W. Wang, H. Che, X. Zhang, Y. Bai, L. Zhang, Z. Fu, Ceram. Intern. 43, 1904 (2017).

[13] C.H. Jung, M.J. Lee, C.J. Kim, Mater. Lett. 58, 609 (2004).

[14] A. Alizadeh, E. Taheri-Nassaj, N. Ehsani, J. Eur. Ceram. Soc. 24, 3227 (2004).

[15] A. Sinha, T. Mahata, B.P. Sharma, J. Nucl. Mater. 301, 165 (2002).

[16] Y.H. Gao, Y. Bando, K. Kurashima, T. Sato, J. Mater Sci. 37, 2023 (2002).

[17] F. Çalıskan, E. Kocaman and S. Cömert, Acta Phys. Pol. A 131, 437 (2017). 